\title{
Effect of pH on Biosorption Ion Cd(II) in Solutions using Lengkuas Merah (Alpinia Gralanga)
}

\author{
Ahmad Faris Fauzi, and Lisa Utami* \\ Jurusan Pendidikan Kimia, Universitas Islam Negeri Sultan Syarif Kasim Riau Pekanbaru \\ JI. HR. Soebrantas No. 155 KM. 18, Simpang Baru, Panam, Pekanbaru 28293 \\ *)E-mail : 1154_lazoelva@yahoo.com
}

\begin{abstract}
The biosorption characteristic of $\mathrm{Cd}(\mathrm{II})$ ions from aqueous solution using Lengkuas Merah (Alpinia Gralanga) were investigated as a function of $\mathrm{pH}$. The maximum biosorption capacity of a Lengkuas Merah (Alpinia Gralanga) for $\mathrm{Cd}(\mathrm{II})$ was found to be $18,37 \mathrm{mg} / \mathrm{L}$ and $91,85 \%$ at optimum $\mathrm{pH}$ was 10 . At $\mathrm{pH} 2$ to 10 the biosorption of $\mathrm{Cd}$ ions tends to increase. The result showed that the lengkuas merah can be evaluated as an alternative biosorbent to treatment waste water containing $\mathrm{Cd}(\mathrm{II})$. A Lengkuas Merah is low cost and has considerable high biosorption capacity.
\end{abstract}

Keywords: Biosorption; lengkuas Merah; Cd (II)

\section{Pendahuluan}

Munculnya logam berat yang mencemari ekosistem air yang berasal dari pembuangan aliran limbah berbagai industri sangat berbahaya bagi makhluk hidup dan lingkungan. Logam berat tidak dapat terurai dan bersifat racun bagi organisme air, logam ini juga dapat terakumulasi dalam rantai makanan. Oleh karena itu, penghilangan logam berat dalam air dan limbah cair sangat penting dilakukan. Kadmium adalah polutan yang berasal dari industri penyepuhan, metalurgi, penambangan, keramik dan operasi industri lainnya. Keracunan kadmium dapat menyebabkan berbagai macam sindrom dan efek seperti hipertensi, gagal ginjal, kerusakan paru-paru, radang hati dan cacat pada janin $1 .^{1}$

Metoda yang paling umum digunakan untuk memisahkan logam-logam berat dari limbah cair adalah pengendapan secara kimia yaitu dengan menambahkan bahan kimia yang dapat mengendapkan logam berat sebagai hidroksidanya, pertukaran ion, adsorpsi, teknologi membran, osomosis terbalik, proses elektrokimia dan ekstraksi pelarut. Metoda pengendapan dapat memisahkan logam berat dalam jumlah yang relatif besar, tetapi dinilai belum efektif dan tidak ekonomis karena membutuhkan biaya yang tinggi. Teknik alternatif yang banyak dikembangkan untuk memisahkan ion-ion logam berat dari limbah cair adalah dengan memanfaatkan biomaterial tumbuhan seperti kulit kacang polong, kulit jeruk, bubuk tempurung kelapa dan dedak padi yang telah diteliti kemampuannya sebagai adsorben ion-ion logam berat dan radionuklida terlarut dari limbah cair. $^{2}$

Metode adsorpsi menggunakan biomassa disebut juga biosorpsi, yaitu menggunakan adsorben dari biomassa sebagai penyerap ion logam yang terkandung dalam limbah sehingga kandungan ion logam dalam air limbah menjadi turun. Proses biosorpsi didasarkan pada interaksi ion logam dengan gugus fungsional yang ada pada permukaan adsorben, melalui interaksi pembentukan kompleks dan biasanya 
terjadi pada permukaan padatan yang kaya gugus fungsional seperti $-\mathrm{OH},-\mathrm{SH},-\mathrm{NH},-\mathrm{COOH}^{3}$ Keuntungan menerapkan metode biosorpsi untuk penanganan limbah logam berat adalah pengolahan yang sederhana dan efisiensi tinggi. ${ }^{4}$

Sejak dahulu, tanaman indonesia telah menjadi bahan penelitian dan kajian mendalam oleh pakar dunia. Salah satu bentuk kekayaan produk hayati indonesia yang terkenal adalah rempah-rempah. Lengkuas yang merupakan anggota famili Zingeberaceae adalah salah satu jenis rempah-rempah yang ada di indonesia. Adapun untuk pemanfaatan lengkuas, sampai saat ini hanya terdapat pada bagian umbi, bunga dan daun saja. Pada umumya bagian-bagian lengkuas tersebut digunakan sebagai salah satu bahan obatobatan dan masakan. Di Indonesia ketika masa pemanenan lengkuas dilakukan, bagian dari batang lengkuas sering kali dibuang begitu saja tanpa dimanfaatkan terlebih dahulu.

Berdasarkan penelitian sebelumnya dijelaskan bahwa daun dan batang lengkuas putih dapat dijadikan sebagai biosorben terhadap logam berat timbal $(\mathrm{Pb})$ dan logam berat zinc $(\mathrm{Zn}) .{ }^{5}$ Sedangkan pemanfaatan untuk batang lengkuas merah yang memiliki hubungan keluarga dengan lengkuas putih sebagai biosorben sampai saat ini belum dilakukan. Potensi batang lengkuas putih yang telah dijadikan biosorben seharusnya dapat juga digunakan dengan menggunakan batang lengkuas merah. Sehingga, selain membantu mengurangi hasil pembuangan limbah pertanian yang dihasilkan, juga dapat menaikkan nilai ekonomis dari pemanfaatan limbah tersebut. Penelitian ini bertujuan untuk mengetahui kharakteristik biosorpsi khususnya pengaruh $\mathrm{pH}$ terhadap biosorpsi ion $\mathrm{Cd}(\mathrm{II})$ dalam larutan menggunakan batang lengkuas merah (Alpinia Gralanga).

\section{Metodologi Penelitian}

\subsection{Alat dan Bahan}

Alat yang digunakan dalam penelitian ini adalah pH meter, FTIR, beaker glass volume 2 liter, botol sampel, grinder, saringan 150 mesh, gelas ukur, labu ukur, corong, Spektrofotometer Serapan Atom (SSA), neraca analitik, desikator, Stopwatch, botol plastik, oven, pipet volume, kertas saring, gunting, plastik penutup botol sampel, kertas label dan labu ukur. Sedangkan bahan bahan yang digunakan dalam penelitian ini adalah batang lengkuas merah, $\mathrm{Cd}\left(\mathrm{NO}_{3}\right)_{2}$, Larutan $\mathrm{NaOH} 0,05 \mathrm{M}$, Larutan $\mathrm{HNO}_{3}$ 0,05 $\mathrm{M}$ dan $1 \mathrm{M}$, aquades, larutan standar kadmium murni $20 \mathrm{mg} / \mathrm{L}$.

\subsection{Prosedur Kerja}

Batang lengkuas merah yang digunakan sebagai biosorben didapatkan di daerah sungai mandau, Kabupaten Siak Riau. Batang lengkuas merah yang didapatkan kemudian dicuci dan dibilas dengan aquades bebas ion, setelah bersih kemudian dipotong-potong menjadi bagian yang lebih kecil dikeringkan dibawah sinar matahari. Batang lengkuas merah yang telah kering direndam dengan larutan asam nitrat $0,1 \mathrm{M}$ selama satu jam kemudian dicuci dan dibilas dengan akuades sampai air hasil pencucian kembali netral, kemudian keringkan kembali dengan cara yang sama, kemudian sampel dihaluskan sampai berukuran 150 um kemudian disimpan dalam desikator dan siap digunakan sebagai biosorben. Analisis gugus fungsional dalam batang lengkuas merah dilakukan dengan FTIR sedangkan kemampuan biosorpsi batang lengkuas merah dilihat dengan menggunakan AAS.

\subsubsection{Pengaruh pH Terhadap Penyerapan Ion Logam Cd}

Sebanyak 0,1 g batang lengkuas merah yang telah dihaluskan ditambahkan ke dalam $25 \mathrm{ml}$ larutan ion logam $\mathrm{Cd}^{2+}$ dengan konsentrasi 20 $\mathrm{mg} / \mathrm{L}$ dengan variasi $\mathrm{pH} 2,4,6,8$ dan 10 dalam tabung erlenmeyer100 ml. $\mathrm{pH}$ diatur dengan menggunakan $\mathrm{HNO}_{3}$ 0,05 $\mathrm{M}$ atau NaOH 0,05 M. Kemudian dilakukan pengadukan selama 60 menit dengan kecepatan $100 \mathrm{rpm}$. Larutan di dekantasi kemudian disaring dengan kertas saring dan filtrat di kirim ke labor untuk diuji dengan AAS. Setiap percobaan dilakukan pengulangan sebanyak dua kali.

\section{Hasil dan Diskusi}

\subsection{Pembuatan Biosorben dari Batang Lengkuas Merah \\ Pada penelitian ini dilakukan pengolahan} limbah batang lengkuas merah menjadi biosorben dengan langkah awal memotong limbah batang lengkuas menjadi bagian yang lebih kecil. Tahap selanjutnya dilakukan pengeringan terhadap batang 
lengkuas merah dan dilanjutkan dengan merendam batang lengkuas merah tersebut kedalam asam nitrat. Tujuan dilakukannya perendaman adalah untuk mengurangi pengotor-pengotor atau kandungan logam yang masih terikat pada dinding sel batang lengkuas merah melalui pertukaran ion. Setelah direndam dengan asam nitrat, batang lengkuas merah dicuci kembali menggunakan aquades hingga $\mathrm{pH}$ air cucian mendekati netral. Reaksi pelepasan ion logam adalah sebagai berikut ${ }^{6}$ :

$$
\text { M-Biomassa }+2 \mathrm{HNO}_{3} \rightarrow \mathrm{M}^{2+}+2 \mathrm{H} \text {-Biomassa }
$$

Setelah batang lengkuas merah direndam dengan asam nitrat dan dicuci dengan aquades, kemudian batang lengkaus merah di keringkan kembali dibawah sinar matahari hingga kadar air yang ada pada batang lengkuas merah berkurang.

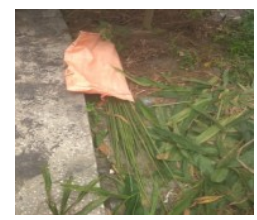

Gambar 1. Batang lengkuas merah

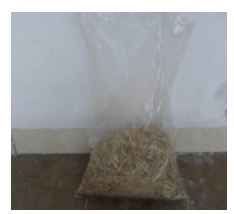

Gambar 2. Biosorben Lengkuas Merah

Sebelum dikontakan dengan limbah logam kadmium, biosorben terlebih dahulu dihaluskan dengan menggunakan alat penghalus (grinder) sehingga didapatkan ukuran biosorben yang lebih kecil yaitu 150 mesh. Salah satu faktor yang mempengaruhi kecepatan reaksi antara biosorben dengan limbah logam kadmium yang diserap adalah ukuran partikel. Semakin kecil ukuran partikel biosorben maka akan semakin luas bidang kontak sehingga terserapnya limbah kadmium akan semakin banyak terjadi. Hasil yang kurang lebih sama diperoleh bahwa efektifitas karbon aktif ukuran 140 mesh lebih tinggi dibandingkan dengan karbon aktif ukuran 50 dan 100 mesh. Hal ini dikarenakan karbon aktif ukuran 140 mesh memiliki luas permukaan yang lebih besar dibandingkan ukuran 50 mesh dan 100 mesh. $^{7}$

\subsection{Hasil Analisis FTIR}

Analisis spektrofotometer FTIR bertujuan untuk identifikasi gugus fungsi dan melihat pergeseran daerah serapan IR sebelum dan sesudah pengontakan dengan limbah logam kadmium. Sampel diidentifikasi pada interval bilangan gelombang $400-4400 \mathrm{~cm}^{-1}$. Selanjutnya perlakuan ini akan memberikan informasi mengenai mekanisme ikatan dan gugus fungsi yang mungkin terlibat berinteraksi dengan ion logam. Analisis FTIR ini dilakukan dengan melihat adanya perubahan dari spektrum IR sebelum dan sesudah biosorpsi ion logam Cd (II) oleh batang lengkuas merah.

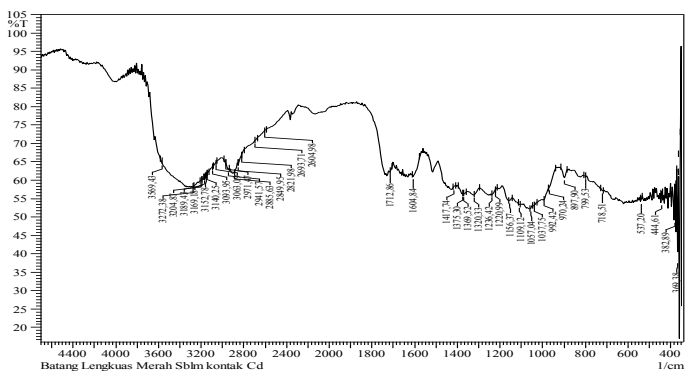

Gambar 3 Spektrum FTIR dari Batang Lengkuas Merah Sebelum dikontakan dengan Logam

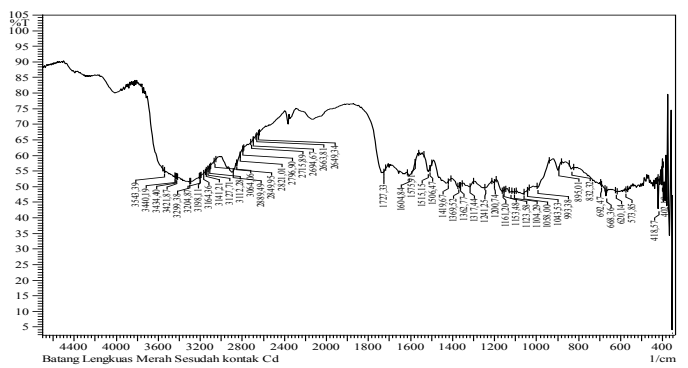

- Gambar 4 Spektrum FTIR dari Batang Lengkuas Merah Sesudah dikontakan dengan Logam

Berdasarkan spektrum FTIR biosorben sebelum dikontakan dengan logam Cd (II) (Gambar 3) tampak serapan disekitar bilangan gelombang $3569,43 \mathrm{~cm}^{-1}$ yang merupakan serapan dari gugus alkohol. Adanya serapan disekitar bilangan gelombang $3140,25 \mathrm{~cm}^{-1}$ merupakan serapan vibrasi ulur dari gugus N-H amida. Pita serapan disekitar bilangan gelombang 2885,63 $\mathrm{cm}^{-1}$ menunjukan adanya serapan dari gugus $\mathrm{C}-\mathrm{H}$ aldehid dan serapan disekitar bilangan gelombang $2604,98 \mathrm{~cm}^{-1}$, serapan ini menunjukan adanya serapan dari gugus fungsi $\mathrm{OH}^{-}$dari asam 
karboksilat. Adanya pita serapan disekitar bilangan gelombang 1712,86 $\mathrm{cm}^{-1}$ menunjukan adanya serapan dari gugus $\mathrm{C}=\mathrm{O}$ karbonil. Adanya serapan di sekitar bilangan gelombang $1575,91 \mathrm{~cm}^{-1}$ menunjukan adanya serapan gugus fungsi $\mathrm{C}=\mathrm{C}$ aromatik. Sedangkan pita serapan disekitar bilangan gelombang $1515,15 \mathrm{~cm}^{-1}$ menunjukan adanya serapan dari gugus fungsi $\mathrm{NO}_{2}$ nitro.

Berdasarkan spektrum FTIR dari biosorben batang lengkuas merah setelah beriteraksi dengan Cd (II) (Gambar 4), terlihat adanya pergeseranpergeseran bilangan gelombang yang dapat disajikan pada Tabel 1.

Tabel 1. Spektrum FTIR Sebelum dan Sesudah Biosorpsi dengan Ion Logam

\begin{tabular}{|c|c|c|c|}
\hline No & $\begin{array}{l}\text { Sebelum } \\
\text { Menyerap }\end{array}$ & $\begin{array}{l}\text { Sesudah } \\
\text { Menyerap }\end{array}$ & Keterangan \\
\hline 1 & $3569,43 \mathrm{~cm}^{-1}$ & $3543,39 \mathrm{~cm}^{-1}$ & $\begin{array}{l}\mathrm{OH} \text { dari } \\
\text { alkohol }\end{array}$ \\
\hline 2 & $2604,98 \mathrm{~cm}^{-1}$ & $2649,34 \mathrm{~cm}^{-1}$ & $\begin{array}{l}\mathrm{OH} \text { dari } \\
\text { asam } \\
\text { karboksilat }\end{array}$ \\
\hline 3 & $3140,25 \mathrm{~cm}^{-1}$ & $3141,21 \mathrm{~cm}^{-1}$ & $\mathrm{~N}-\mathrm{H}$ \\
\hline 4 & $1057,04 \mathrm{~cm}^{-1}$ & $1058,00 \mathrm{~cm}^{-1}$ & C-O Ester \\
\hline 5 & $2885,63 \mathrm{~cm}^{-1}$ & $2889,49 \mathrm{~cm}^{-1}$ & C-H aldehid \\
\hline 6 & $1037,75 \mathrm{~cm}^{-1}$ & $1043,53 \mathrm{~cm}^{-1}$ & C-O eter \\
\hline 7 & $1604,84 \mathrm{~cm}^{-1}$ & $1604,84 \mathrm{~cm}^{-1}$ & $\mathrm{C}=\mathrm{C}$ alkena \\
\hline 8 & & ${ }_{1}^{1575,91 \mathrm{~cm}^{-}}$ & $\begin{array}{l}\mathrm{C}=\mathrm{C} \\
\text { aromatik }\end{array}$ \\
\hline 9 & $1712,86 \mathrm{~cm}^{-1}$ & $1727,33 \mathrm{~cm}^{-1}$ & $\mathrm{C}=\mathrm{O}$ \\
\hline 10 & & $1515,15 \mathrm{~cm}^{-1}$ & $\mathrm{R}-\mathrm{NO}_{2}$ nitro \\
\hline
\end{tabular}

Gugus fungsi yang mengalami pergeseran bilangan gelombang tersebut diasumsikan sebagai gugusgugus fungsi yang kemungkinan berperan dalam proses adsorpsi. Hasil spektra adsorben setelah adsorpsi menunjukan adanya serapan pada $3569,43 \mathrm{~cm}^{-1}$. Ini memperlihatkan bahwa adanya pergeseran daerah IR sebelum dan sesudah adsorpsi. Hal ini diasumsikan telah terjadi pengikatan $\mathrm{Cd}$ (II) oleh -OH selama proses adsorpsi. Berdasarkan data tersebut dapat diasumsikan bahwa proses adsoprsi Cd (II) mengikuti mekanisme pertukaran ion.

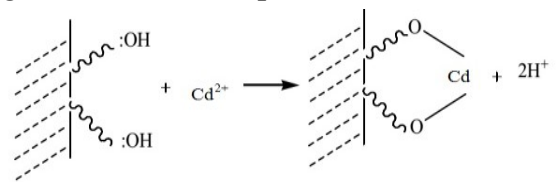

Gambar 5 Mekanisme Pertukaran Ion

Hasil ini memperlihatkan bahwa ikatan yang terjadi antara gugus aktif pada molekul organik dengan ion logam Cd (II) merupakan perilaku interaksi asam-basa lewis yang menghasilkan ikatan kompleks pada pemukaan adsorben.

$$
\begin{aligned}
\mathrm{GH}]+\mathrm{Cd}^{2+} & \rightarrow\left[\mathrm{GCd}^{(2-1)}\right]+\mathrm{H}^{+} \\
2[\mathrm{GH}]+\mathrm{Cd}^{2+} & \rightarrow\left[\mathrm{G}_{2} \mathrm{Cd}^{(2-2)}\right]+2 \mathrm{H}^{+}
\end{aligned}
$$

Interaksi antara gugus $-\mathrm{OH}$ dengan ion logam juga dapat terjadi dengan mekanisme pembentukan kompleks koordinasi karena atom oksigen $(\mathrm{O})$ pada gugus - $\mathrm{OH}$ mempunyai elektron bebas. Sedangkan ion logam mempunyai orbital $\mathrm{d}$ yang kosong. Pasangan elektron bebas tersebut akan mengisi orbital yang dipunyai ion logam dan akhirnya terbentuk senyawa atau ion kompleks. ${ }^{8}$

\subsection{Hasil Adsorpsi Ion Logam Cd (II) oleh Biosorben Pada Variasi pH}

Proses adsorpsi dilakukan pada variasi $\mathrm{pH}$ bertujuan untuk mengetahui $\mathrm{pH}$ optimum biosorben dalam menyerap ion logam Cd (II). Kemampuan biosorben dalam menurunkan kadar logam dapat dilihat pada kurva pengaruh $\mathrm{pH}$ terhadap \% biosorpsi yang terlihat pada gambar 6 .

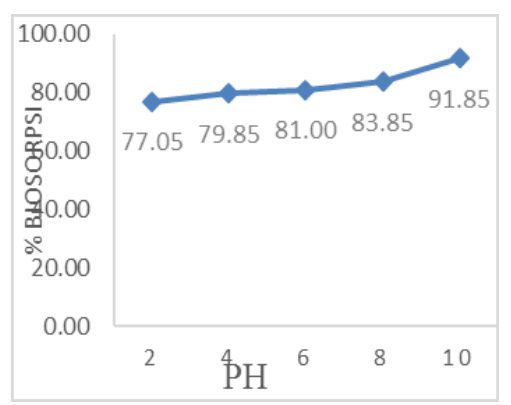

Gambar 6 Kurva Pengaruh $\mathrm{pH}$ terhadap \% Biosorpsi Cd (II) Menggunakan Batang Lengkuas Merah 
Tingkat keasaman atau $\mathrm{pH}$ berpengaruh besar terhadap adsorpsi. Keadaan $\mathrm{pH}$ larutan mempengaruhi muatan pada permukaan adsorben, demikian halnya perubahan $\mathrm{pH}$ dapat mempengaruhi proses adsorpsi gugus fungsi pada permukaan adsorben. Variabel $\mathrm{pH}$ larutan merupakan hal penting dalam adsorpsi ion logam karena ion hidrogen merupakan ion yang berkompetisi kuat dengan ion logam. Untuk mengetahui pengaruh $\mathrm{pH}$ pada proses adsorpsi, perlakuan dilakukan pada nilai $\mathrm{pH}$ yang berbedabeda. Kondisi pH optimum ditentukan berdasarkan jumlah adsorpsi tertinggi biosorben batang lengkuas merah terhadap ion logam kadmium.

Tabel 2 Data Adsorpsi Variasi pH

\begin{tabular}{lllll}
\hline $\mathbf{p H}$ & $\begin{array}{l}\mathbf{C e} \\
(\mathbf{m g} / \mathbf{l})\end{array}$ & $\begin{array}{l}\mathbf{C} \\
\text { teradsorpsi } \\
(\mathbf{m g} / \mathbf{L})\end{array}$ & $\begin{array}{l}\text { Qe } \\
(\mathbf{m g} /\end{array}$ & $\begin{array}{l}\mathbf{\%} \\
\text { Biosor } \\
\mathbf{p s i}\end{array}$ \\
& & & & \\
\hline $\mathbf{2}$ & 20 & 15,41 & 4,59 & $77,05 \%$ \\
$\mathbf{4}$ & 20 & 15,97 & 4,03 & $79,85 \%$ \\
$\mathbf{6}$ & 20 & 16,2 & 3,80 & $81 \%$ \\
$\mathbf{8}$ & 20 & 16,77 & 3,23 & $83,85 \%$ \\
$\mathbf{1 0}$ & 20 & 18,37 & 1,63 & $91,85 \%$ \\
\hline
\end{tabular}

Tabel 2 menunjukkan pengaruh $\mathrm{pH}$ terhadap jumlah ion $\mathrm{Cd}$ (II) yang diadsorpsi. $\mathrm{pH}$ optimum adsorpsi ion Cd (II) oleh biosorben batang lengkuas merah adalah 10 dengan jumlah ion yang diadsorpsi adalah $18,37 \mathrm{mg} / \mathrm{L}$ dan persentase $91,85 \%$. Pada tabel 2 memperlihatkan bahwa pada $\mathrm{pH} 2$ sampai 10, adsorpsi ion Cd (II) cenderung meningkat. Hal ini menunjukkan bahwa biosorben batang lengkuas merah mengadsorpsi ion logam pada $\mathrm{pH}$ lebih basa. Muatan negatif pada permukaan biosorben paling besar terjadi pada $\mathrm{pH}$ 10 , sehingga ion positif logam lebih banyak terikat. Sedangkan pada $\mathrm{pH}$, ion logam yang terikat lebih kecil karena permukaan adsorben cenderung terprotonasi atau lebih positif sehingga penolakan biosorben terhadap ion logam berat terjadi lebih cepat.

Rendahnya serapan ion Cd (II) pada $\mathrm{pH}$ yang lebih asam diakibatkan karena asam amino terprotonsi, dimana atom $\mathrm{H}^{+}$dari gugus karboksil akan berikatan dengan gugus amino membentuk $\mathrm{NH}_{3}{ }^{+}$, sedangkan pada selulosa dengan bertambahnya ion $\mathrm{H}^{+}$maka, ion $\mathrm{H}^{+}$tersebut akan berikatan dengan gugus hidroskil pada selulosa membentuk $\mathrm{OH}_{2}{ }^{+}$. Pada $\mathrm{pH}$ rendah dalam larutan, konsentrasi ion $\mathrm{H}^{+}$lebih banyak sehingga akan terjadi kompetisi ion-ion logam $\mathrm{Cd}$ (II) untuk berikatan dengan atom $\mathrm{N}$ dari gugus amino dan atom $\mathrm{O}$ dari gugus hidroksil selulosa yang merupakan tempat utama ikatan logam dengan biomassa. Terbentuknya gugus $\mathrm{NH}_{3}^{+}$dan gugus $\mathrm{OH}_{2}$ menyebabkan terjadinya gaya tolak antar sisi aktif dari asam amino dan selulosa yang bermuatan positif dengan ion $\mathrm{Cd}$ (II) yang juga bermuatan positif. ${ }^{9}$

Sedangkan peningkatan serapan Cd (II) pada $\mathrm{pH}$ yang lebih tinggi atau pada $\mathrm{pH}$ optimum disebabkan karena sisi aktif dari penyusun protein dan selulosa dalam biomassa muatannya cenderung berubah menjadi negatif, sehingga ion logam dapat berikatan dengan gugus-gugus aktif yang ada di dalam biomassa. Untuk berikatan, ion logam akan menggantikan kedudukan atom $\mathrm{H}$ pada gugus hidroksil selulosa dan gugus karboksil serta gugus amina pada protein membentuk ikatan koordinasi sehingga ion Cd (II) yang bermuatan positif dapat terjadi, sehingga terjadi penyerapan secara maksimal.

Hasil yang kurang lebih sama diperoleh dari hasil penelitian penyerapan optimum ion $\mathrm{Zn}$ (II) dengan menggunakan batang dan daun lengkuas putih dengan variasi pH 2 sampai dengan 7 dimana penyerapan optimum ion logam terjadi pada $\mathrm{pH} 7$.

\section{Kesimpulan}

$\mathrm{pH}$ optimum adsorpsi ion Cd (II) oleh biosorben batang lengkuas merah adalah 10 dengan jumlah ion yang diadsorpsi adalah $18,37 \mathrm{mg} / \mathrm{L}$ dan persentase 91,85\%. Hal ini menunjukkan bahwa biosorben batang lengkuas merah mengadsorpsi ion logam pada $\mathrm{pH}$ lebih basa. Hasil penelitian menunjukkan bahwa lengkuas merah dapat digunakan untuk mengolah limbah yang mengandung ion logam $\mathrm{Cd}(\mathrm{II})$.

\section{Referensi}

1. Sari, Amet, Tuzen, Mustafa. 2009. Kinetic and Equilibrium Studies of Biosorption of $\mathrm{Pb}(\mathrm{II})$ and Cd(II) From Aqueous Solution by Macrofungus (Amanita Rubescens) Biomass. Journal of Hazardous Materials 164. 
2. Mawardi, Munaf, Edison, dkk. 2014. Pemisahan Ion Kromium (III) dan Kromium (IV) Dalam Larutan dengan Menggunakan Biomassa Alga Hijau Spirogyra Subsalsa Sebagai Biosorben. Reaktor Vol. 15.

3. Purwaningsih, Diah. 2009. Adsorpsi Multi Logam Ag (I), Pb (II), Cr (III), dan Ni (II) Pada Hibrida Etilendiamino-Silika Dari Abu Sekam Padi, Yogyakarta : Universitas Negeri Yogyakarta.hlm. 264.

4. Mulyawan, Reza. 2015. Biosorpsi Timbal Oleh Biomassa Daun Ketapang. Bogor : Universitas Indonesia, Molekul, Vol.10.No, hlm. 46.

5. Chairgulprasert, Vanida. 2013. Phytoremediation of Synthetic Wastewater by Adsorption of Lead and Zinc onto Alpinia galanga Willd. Pattani : Prince of Songkla University.

6. Komari, Noer. 2012. Adsorpsi Pb2+ dan Zn2+ pada Biomassa Imperata Cylindrica. Banjarbaru : Universitas Lambung Mangkurat. Valensi Vol. 2, No. 5, hlm. 558.

7. Elmariza, Juli. 2015. Optimasi Ukuran Partikel, Massa dan Waktu Kontak Karbon Aktif berdasarkan Efektifitas Adsorpsi $\beta$ Karoten Pada CPO. Pontianak :Universitas Tanjungpura. JKK. Vol. 4, No. 2, hlm. 24.

8. Amr, Amuni. 2004. Kesetimbangan Adsorpsi Optional Campuran Biner Cd(II) dan Cr(III) dengan Zeolite Alam Terimpregnasi ZMerkapto Benzotiazol. Jurnal Natur Indonesia, Vol. 6, No. 2 , hlm. 112.

9. Abriagni, Dana. 2011. Optimasi Adsorpsi Krom (VI) Dengan Ampas Daun Teh (Camellia Sinensis L) Menggunakan Metode Spektrofotometri. Semarang : Skripsi Program Studi Pendidikan Kimia, FMIPA Universitas Negeri Semarang. hlm.16.

10. Suhu, Iffatunniswah. 2012. Adsorpsi Ion Kadmium (II) Dari Larutannya Menggunakan Biomassa Akar dan Batang Kangkung Air (Ipomoea Aquatica Forks), Palu : University of Tadulako, J. Akad. Kim. Vol. 1, No. 4, hlm. 156. 